\title{
Pelatihan Pembuatan Penilaian Otentik bagi Guru-Guru Bahasa Inggris SMP di Kota Padang
}

\author{
Sitti Fatimah*)1, Fitrawati ${ }^{2}$, Yetty Zainil ${ }^{3}$ \\ ${ }^{1}$ Prodi Pendidikan Bahasa Inggris \\ ${ }^{2}$ Prodi Pendidikan Bahasa Inggris \\ 3Prodi Pendidikan Bahasa Inggris \\ *)Corresponding author, $\equiv$ sitti.fatimah@fbs.unp.ac.id
}

(Di isi oleh editor)

Revisi 05/12/2019;

Diterima 03/01/2020

Publish 01/02/2020
Kata kunci: penilaian otentik (authentic assessment), pembelajaran Bahasa Inggris, sekolah menengah pertama

\begin{abstract}
Abstrak
Tujuan dari kegiatan ini adalah untuk mengadakan pelatihan pembuatan penilaian otentik bagi guru-guru Bahasa Inggris SMP di kota Padang. Pelatihan ini diadakan di Forum MGMP (Majelis Guru Mata Pelajaran) yang melibatkan tiga orang dosen Prodi Pendidikan Bahasa Inggris, Jurusan Bahasa dan Sastra Inggris, Universitas Negeri Padang. Peserta diperkenalkan dengan berbagai bentuk penilaian otentik dan dilatih untuk membuat soal-soal ataupun tugas yang bersifat otentik yang dilakukan dengan latihan terbimbing dan mandiri. Pelatihan ini dilanjutkan melalui email dan aplikasi whats app dimana peserta pelatihan yang mewakili beberapa sekolah mengirimkan soal-soal yang dibuat berdasarkan konsep penilaian otentik. Soal tersebut kemudian dikoreksi dan diberikan masukan dan dikirimkan kembali kepada mereka supaya mereka dapat memperbaiki dan menggunakannya untuk menilai capaian pembelajaran siswa. Dari soal-soal yang dibuat oleh guru pada tahap awal latihan terbimbing masih banyak yang membuat secara tradisional atau belum menerapkan prinsip penilaian otentik. Namun pada tahap berikutnya sudah terlihat pemahaman sebagian guruguru tersebut.
\end{abstract}

\section{PENDAHULUAN}

\section{Analisis Situasi}

Di dalam Undang-undang tentang Sertifikasi Guru tahun 2007 memuat tiga jenis kompetensi utama yang harus dikuasai oleh guru sebagai agen perubah wajah pendidikan di Indonesia. Kompetensi tersebut adalah: kompetensi professional, pedagogik, dan sosial. Kompetensi pedagogik merupakan kemampuan mengelola pembelajaran peserta didik yang meliputi pemahaman peserta didik, perancangan dan pelaksanaan pembelajaran, evaluasi hasil belajar dan pengembangan peserta didik untuk mengaktualisasikan berbagai potensi yang dimilikinya (Mulyasa, 2009). Salah satu kompetensi guru dalam dimensi pedagogik adalah dapat menyelenggarakan penilaian, evaluasi proses dan hasil belajar, dengan kompetensi inti diantaranya dapat menentukan aspek-aspek proses dan hasil belajar yang penting untuk dinilai dan dievaluasi sesuai dengan karakteristik lima mata pelajaran SMP dan mengembangkan 
instrumen penilaian dan evaluasi proses dan hasil belajar. Pada hakikatnya, penilaian adalah proses pengumpulan dan pengolahan informasi.

Kendala lain yang dianggap klasik namun sulit dipecahkan adalah sistem penilaian prestasi siswa yang hanya bisa mengukur siswa secara parsial dan tidak mengacu kepada proses pembelajaran yang telah dilalui oleh siswa. Alasan yang diberikan juga klasik, misalnya ketidakcukupan waktu dan tenaga dalam menguji siswa dengan menggunakan sistem penilaian yang lebih komprehensif. Ini merupakan masalah lama yang sampai sekarang masih menjadi polemik bidang pengajaran di Indonesia.

Dalam pendidikan, penilaian berarti proses pengumpulan dan pengolahan informasi untuk menentukan pencapaian hasil belajar peserta didik. Untuk melaksanakan penilaian, guru memerlukan instrumen penilaian dalam bentuk soal-soal, baik untuk menguji aspek kognitif, afektif, maupun psikomotor. Instrumen penilaian yang digunakan guru untuk menguji hasil belajar peserta didik pada aspek kognitif biasanya diambil dari berbagai buku atau kumpulan soal-soal ujian. Kenyataan di lapangan, soal-soal cenderung menggunakan model penilaian standar (standardized test) yang berbentuk pilihan ganda, mengisi rumpang dan memilih jawaban Benar atau Salah. Banyak buku yang menyajikan materi dengan kegiatan pembelajaran yang mengajak peserta didik belajar aktif dengan mengerjakan latihan-latihan terstruktur, tetapi sering diakhiri oleh soal evaluasi yang kurang menilai pencapaian hasil belajar peserta didik secara komprehensif dan tidak mengaitkannya dengan kehidupan nyata siswa. Dengan melakukan penilaian otentik ini guru mendapatkan gambaran yang lebih luas tentang kemampuan siswa terhadap proses pembelajaran dan apa yang telah dipelajarinya.

Namun, sebagian besar guru Bahasa Inggris SMP di Sumatera Barat tidak mengetahui atau kurang memahami bagaimana membuat penilaian otentik. Salah satu penyebabnya adalah kekurangpengetahuan guru tentang konsep penilaian otentik yang sangat ditekankan pada kurikulum nasional 2013. Secara umum mereka masih menggunakan penilaian konvensional. Sebagian lain menganggap bahwa penilaian otentik (authentic assessment) adalah haruslah tidak subjektif (objective), valid dan reliable. Padahal semua penilaian haruslah memiliki ketiga unsur yang mereka pahami tersebut. Dari 29 orang guru Bahasa Inggris SMP dari berbagai daerah di Sumatera Barat yang diwawancarai, diketahui bahwa tidak satupun dari mereka pernah mendapatkan pengetahuan dan keterampilan tentang penilaian otentik tersebut. Mereka sangat buta dengan konsep penilaian otentik ini. Dengan alasan inilah, guru-guru Bahasa Inggris SMP perlu mendapatkan pengetahuan dan pelatihan bagaimana membuat penilaian otentik tersebut.

Walaupun dari hasil survei awal diketahui bahwa permasalahan tentang kurangnya pengetahuan dan keterampilan guru Bahasa Inggris SMP tentang penilaian otentik terjadi pada kebanyakan guru di Sumatera Barat, karena keterbatasan dana dan tenaga, melalui PKM ini pelatihan hanya akan diberikan kepada guru-guru di kota Padang melalui forum MGMP (Musyawarah Guru Mata Pelajaran) Bahasa Inggris. Forum MGMP ini diadakan setiap hari Selasa dimana hampir semua guru-guru Bahasa Inggris di kota Padang berkumpul untuk mendapatkan berbagai pelatihan. Untuk 4 (empat) kali pertemuan, mereka akan diberikan penjelasan tentang language assessment yang akan ditekankan pada penilaian otentik.

\section{Solusi dan Target}

A. Solusi

Solusi yang ditawarkan terhadap permasalahan yang terjadi pada guru Bahasa Inggris SMP adalah sebagai berikut:

1. Memberikan pengetahuan kepada guru tentang konsep and prinsip asesmen bahasa.

2. Memberikan pengetahuan kepada guru tentang merancang dan mengembangkan instrumen evaluasi hasil belajar.

3. Memberikan pengetahuan teoritis kepada guru-guru tentang penilaian otentik (authentic assessment). 


\section{Suluah Bendang: Jurnal Ilmiah Pengabdian Kepada Masyarakat}

Vol.20, No.2, 2019

Sitti Fatimah, Fitrawati, Yetty Zainil

4. Melatih guru-guru tentang pembuatan penilaian otentik yang dapat menilai pencapaian hasil belajar peserta didik secara komprehensif.

Untuk melaksanakan kegiatan pelatihan agar solusi seperti yang disebutkan di atas dapat diperoleh, maka perlu diuraikan beberapa konsep mendasar tentang penilaian bahasa.

\section{Asesmen dan Ujian (testing)}

Menurut Brown (2010), asesmen dan ujian tidaklah sama. Brown menjelaskan bahwa dalam bidang pendidikan, assesmen adalah proses yang berkelanjutan yang melibatkan sejumlah teknik. Asesmen dapat dilakukan selama proses pembelajaran berlangsung dengan menggunakan berbagai cara. Guru dapat melakukan asesmen kapan saja sepanjang proses pembelajaran, baik secara insidentil ataupun terencana. Misalnya, guru bisa memberikan penilaian diam-diam ketika seorang siswa merespon pertanyaannya atau memberikan komentar terhadap suatu topik.

Sedangkan ujian (test) adalah seperangkat asesment atau salah satu tipe dari teknik penilaian. Ujian biasanya dirancang secara administratif dan dijadwalkan secara teratur, apakah pada pertengahan atau akhir semester. Dalam pengertian ilmiahnya, ujian adalah suatu metode yang digunakan untuk menguji kemampuan, pengetahuan dan performa siswa dalam kurun waktu yang telah dipersiapkan.

\section{Jenis dan Tujuan Asesmen}

Brown (2010) mengemukakan beberapa jenis beserta tujuan diadakannya asesmen sebagaimana dijelaskan di bawah ini.

a. Tes Pencapaian (achievement test). Tes ini dilakukan untuk mengetahui kemampuan siswa setelah mempelajari sebuat topik atau unit.

b. Tes Diagnostik (diagnostic test). Tes ini dilakukan untuk mengdiagnosa aspek dari sebuah bahasa yang harus ditingkatkan oleh seorang siswa.

c. Tes Penempatan (placement test). Tes ini untuk mengklasifikasikan siswa untuk ditempatkan pada level tertentu.

d. Tes Kemampuan (proficiency test). Tes ini tidak terbatas kepada mengukur kemampuan siswa hanya pada satu aspek saja tapi melihat secara keseluruhan.

\section{Penilaian Tradisional dan Otentik}

Penilaian tradisional adalah penilaian yang berorientasi produk karena hanya mengukur kemampuan siswa pada akhir sebuah pembelajaran. Penilaian ini biasanya diberikan dalam bentuk pilihan ganda, mengisi rumpang, memasangkan sebuah topik dengan penjelasannya ataupun menentukan benar atau salah sebuah pernyataan. Penilaian ini hanya mampu mengukur secara cepat dan ringkas kemampuan siswa terhadap sebuah topik yang telah dipelajarinya. Melakukan penilaian tradisional jauh menghemat waktu dan tenaga guru nampun tidak dapat mengukur kemampuan siswa secara utuh.

Sedangkan penilaian otentik (authentic assessment) adalah penilaian yang berorientasi proses dan performa siswa yang mengaitkan dengan kehidupan nyata dari siswa. Penilaian ini dapat mengukur kemampuan siswa secara menyeluruh karena menggunakan berbagai tipe penilaian. Penilaian otentik dapat berupa portofolio, conference, interview dan observasi. Menggunakan penilaian otentik memberikan peluang kepada guru untuk menilai siswa dari berbagai aspek karena tiap siswa memiliki kelebihan dan kekurangan yang berbeda.

\section{B. Target Luaran}

Target dari terlaksananya PKM UNP Melalui Pelatihan Pembuatan Penilaian Otentik melalui MGMP Bahasa Inggris kota Padang adalah sebagai berikut:

1. Meningkatnya pemahaman guru tentang evaluasi hasil belajar

2. Meningkatnya kemampuan guru dalam merumuskan capaian pembelajaran 
3. Meningkatnya pemahaman guru tentang penilaian otentik

4. Meningkatnya kemampuan guru dalam membuat soal yang berdasarkan kepada penilaian otentik.

Berikut adalah rencana target luaran yang akan dicapai dalam kegiatan PKM ini.

Tabel 1. Rencana Target Capaian Luaran

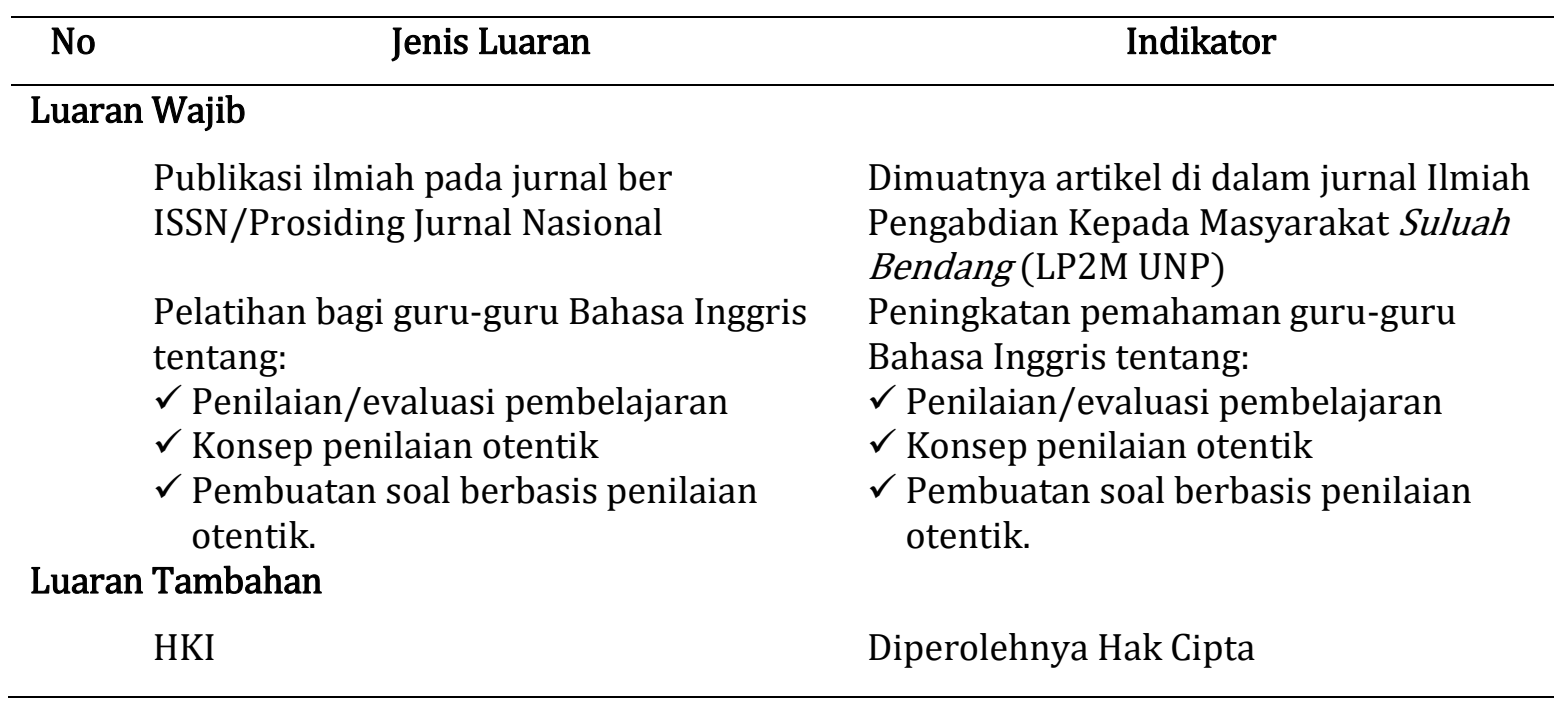

\section{METODE PELAKSANAAN}

Metode yang diterapkan dalam pengabdian ini adalah aplikasi teknologi pembelajaran, dengan mengungkap permasalahan yang muncul dikalangan para guru, kemudian dilakukan diskusi pengusul bersama mitra untuk merumuskan akar masalah prioritas yang disepakati, serta menentukan solusi yang tepat. Secara garis besar langkah-langkah pelaksanaan seperti dicandrakan pada Tabel 2 berikut.

Tabel 2. Langkah-langkah pelaksanaan

\begin{tabular}{lll}
\hline \multicolumn{1}{c}{$\begin{array}{c}\text { Masalah yang dihadapi } \\
\text { mitra }\end{array}$} & \multicolumn{1}{c}{$\begin{array}{c}\text { Penyebab masalah yang } \\
\text { dihadapi mitra }\end{array}$} & \multicolumn{1}{c}{$\begin{array}{c}\text { Pendekatan pemecahan } \\
\text { masalah }\end{array}$} \\
\hline Kurangnya pemahaman & $\checkmark$ Guru-guru bahasa Inggris & $\checkmark$ Memberikan wawasan yang \\
guru bahasa Inggris & tidak mendasarkan pada & jelas tentang bagaimana \\
mengenai & tujuan dan capaian & menyusun tes evaluasi \\
penilaian/evaluasi & pembelajaran yang telah & belajar yang benar sesuai \\
pembelajaran & ditentukan dalam membuat & dengan teori evaluasi \\
& soal. & pembelajaran \\
& $\checkmark$ Pemahaman guru terhadap & $\checkmark$ Memberikan wawasan \\
& penilaian/evaluasi belajar & tentang asesmen hasil \\
& masih rendah & belajar sesuai dengan \\
& & Kompetensi Dasar (KD), \\
& & indikator, tujuan dan \\
& & capaian pembelajaran
\end{tabular}

\begin{tabular}{ccc}
\hline $\begin{array}{c}\text { Masalah yang dihadapi } \\
\text { mitra }\end{array}$ & $\begin{array}{c}\text { Penyebab masalah yang } \\
\text { dihadapi mitra }\end{array}$ & $\begin{array}{c}\text { Pendekatan pemecahan } \\
\text { masalah }\end{array}$ \\
\hline Kurangnya pemahaman & $\checkmark$ Guru-guru Bahasa Inggris & $\checkmark$ Memberikan workshop \\
\hline
\end{tabular}




\section{Suluah Bendang: Jurnal IImiah Pengabdian Kepada Masyarakat}

Vol.20, No.2, 2019

Sitti Fatimah, Fitrawati, Yetty Zainil

\begin{tabular}{|c|c|c|}
\hline $\begin{array}{l}\text { guru Bahasa Inggris } \\
\text { tentang konsep penilaian } \\
\text { otentik (authentic } \\
\text { assessment) }\end{array}$ & $\begin{array}{l}\text { masih terjebak pada } \\
\text { penggunaan penilaian } \\
\text { traditional } \\
\checkmark \text { Guru-guru Bahasa Inggris } \\
\text { tidak memahami konsep } \\
\text { penilaian otentik (authentic } \\
\text { assessment) }\end{array}$ & $\begin{array}{l}\text { tentang konsep penilaian } \\
\text { otentik dan } \\
\text { membedakannya dengan } \\
\text { konsep penilaian } \\
\text { tradisional. }\end{array}$ \\
\hline $\begin{array}{l}\text { Kurangnya kemampuan } \\
\text { guru Bahasa Inggris } \\
\text { dalam membuat soal-soal } \\
\text { ujian harian berbasis } \\
\text { penilaian otentik } \\
\text { (authentic assessment) }\end{array}$ & $\begin{array}{l}\text { - Guru belum pernah } \\
\text { membuat soal berbasis } \\
\text { penilaian otentik. } \\
\text { - Tipe soal yang biasanya } \\
\text { dibuat guru masih bersifat } \\
\text { tradisional. }\end{array}$ & $\begin{array}{l}\text { Memberikan workshop } \\
\text { tentang pembuatan soal } \\
\text { bahasa Inggris berbasis } \\
\text { penilaian otentik. }\end{array}$ \\
\hline
\end{tabular}

Berdasarkan akar permasalahan di atas, maka pendekatan solutif yang digunakan untuk memecahkan tiga permasalahan pokok yang dihadapi oleh sekolah mitra adalah dengan melakukan in-service berupa pelatihan dan pendampingan. Tiga target pelatihan adalah: 1) penyusunan tes evaluasi hasil belajar siswa, 2) pelatihan tentang materi penilaian otentik, dan 3) pelatihan tentang teknik-teknik pembuatan soal Bahasa Inggris berbasis prinsip-prinsip authentic assessment. Pendampingan yang dimaksudkan disini adalah terkait dengan pembuatan asesmen Bahasa Inggris berbasis penilaian otentik. Koordinasi intensif antara guru Bahasa Inggris dengan ketua MGMP dan dengan tim dosen pelaksana kegiatan PKM dilakukan dengan melakukan perencanaan keseluruhan kegiatan, baik pelatihan maupun pendampingan. Pelatihan tentang evaluasi hasil belajar diberikan oleh tim dosen.

Secara detil tahapan kegiatan yang dilakukan dalam pelatihan adalah:

1. Penjabaran kompetensi inti menjadi kompetensi dasar.

2. Penjabaran kompetensi dasar menjadi tujuan pembelajaran.

3. Penjabaran tujuan pembelajaran menjadi indikator dan capaian pembelajaran.

4. Penjabaran mengenai materi pelajaran.

5. Penjabaran tentang penilaian tradisional versus penilaian otentik.

6. Pembuatan evaluasi Bahasa Inggris berbasis penilaian otentik.

7. Pendampingan pembuatan soal Bahasa Inggris berbasis penilaian otentik.

\section{Khalayak Sasaran}

Sasaran dari kegiatan ini adalah guru-guru Bahasa Inggris Sekolah Menengah Pertama se-kota Padang yang tergabung dalam MGMP guru Bahasa Inggris yang berjumlah 150 orang. Jumlah peserta yang besar ini diadakan agar semua guru dapat mengetahui tentang konsep penilaian otentik secara langsung dari nara sumber. Hal ini karena penilaian otentik merupakan kriteria penilaian yang dituangkan dalam Kurikulum 2013 yang menghendaki agar guru sedapatnya menggunakan penilaian otentik dalam mengukur hasil pembelajaran siswa.

\section{Metode Pengabdian}

Metode pengabdian ini dilaksanakan dengan 4 (empat) cara. Pertama, metode ceramah pada awal kegiatan yang berlangsung selama lebih kurang 45-60 menit. Metode ini diselingi dengan metode tanya-jawab antara pemateri dan peserta kegiatan. Kedua, peserta diminta duduk berkelompok untuk membuat soal/tugas dengan mengikuti prinsip-prinsip penilaian otentik. Ketiga, peserta mempresentasikan model soal/tugas yang telah dibuat secara berkolompok dan diberikan umpan balik baik oleh pemateri maupun oleh kelompok lain. Keempat, model soal/tugas yang telah diberikan umpan balik direvisi kembali oleh masingmasing kelompok. 


\section{Indikator Keberhasilan}

Pembuatan penilaian otentik secara umum tidak jauh berbeda dengan pembuatan penilaian tradisional. Hal ini dapat dilakukan oleh siapa saja apalagi oleh guru yang sudah berpengalaman dalam mengajar karena setiap proses pembelajaran pastilah melibatkan diadakannya asesmen. Yang penting diketahui adalah prinsip-prinsip penilaian otentik itu sendiri. Jadi indikator keberhasilan pelatihan ini adalah terlihatnya kemampuan guru-guru Bahasa Inggris dalam merancang penilaian otentik.

\section{Metode Evaluasi}

Untuk melihat keberhasilan kegiatan ini peserta diberi tugas membuat RPP model pembelajaran yang menggambarkan kemampuan guru memilih Kompetensi Dasar (KD) yang akan menjadi acuan pembuatan penilaian otentik. Dari KD yang sudah ditetapkan akan diperoleh indikator, tujuan pembelajaran dan capaian pembelajaran. Selanjutnya guru akan menentukan materi apa yang akan dibuatkan soal dengan konsep penilaian otentik. Soal-soal ini akan dibuatkan dalam bentuk kumpulan soal (BANK SOAL). BANK SOAL ini bisa berupa soal ulangan harian dan soal ujian tengah semester. Sebelum BANK SOAL ini dipakai dan diperbanyak oleh guru di kelas, soal-soal tersebut akan diperiksa dan diberikan komentar oleh para narasumber sesuai dengan konsep penilaian otentik. Pendampingan oleh narasumber ini akan dilakukan dalam beberapa kali sesi sampai pembuatan soal berbasis penilaian otentik yang dilakukan guru sudah benar. Di samping itu, diberikan juga tes untuk menilai pengetahuan guru tentang pengetahuan guru terhadap materi yang sudah diberikan. Penilaian proses diambil dari diskusi kelompok, partisipasi, dan pengembangan pembuatan soal yang dilakukan guru selama pelatihan.

\section{HASIL DAN PEMBAHASAN}

Kegiatan pelatihan yang dilaksanakan dalam empat kali pertemuan telah membuahkan hasil yang memadai terhadap pemahaman dan keterampilan guru dalam membuat penilaian otentik. Sejalan dengan tujuan diadakan pelatihan ini, guru-guru Bahasa Inggris yang tergabung dalam MGMP Guru Bahasa Inggris tingkat SMP diharapkan mampu membuat soal bahasa Inggris otentik sehingga guru bisa mengukur kemampuan dan kemajuan siswa dengan lebih akurat. Adapun rincian dan pembahasan tahapan-tahapan kegiatan pelatihan pembuatan penilaian otentik Bahasa Inggris ini akan diuraikan sebagai berikut.

Pertemuan pertama pada tanggal 3 September 2019 dibuka oleh Pipin Sovia, S.Pd, M.M selaku Ketua MGMP Bahasa Inggris SMP Kota Padang. Materi pada pertemuan pertama ini disampaikan oleh Sitti Fatimah, S.S., M.Ed., PhD tentang penilaian, ujian dan pengajaran, serta hubungan antara ketiganya. Penyajian tentang penilaian diawali dengan materi tentang formal dan informal asesmen sebelum menyajikan tentang materi pokok Penilaian Otentik (Authentic Assessment). Selama penyajian materi juga berlangsung tanya jawab antara peserta pelatihan dan pemateri. Sebagian besar guru memang belum melakukan penilaian otentik karena belum terlalu memahami seperti apa penilaian otentik tersebut. Mereka sudah terbiasa melakukan penilaian secara tradisional yang terkadang tidak bisa mengukur pencapaian pembelajaran siswa. Karena itu pemateri menjelaskan bahwa untuk dapat membuat penilaian yang baik, khususnya penilaian otentik guru harus merumuskan dulu Capaian Pembelajaran (CP) pada setiap Kompetensi Dasar (KD). Konsep CP mengandung dua pertanyaan penting yaitu: "Apa yang harus dipahami oleh siswa?" dan "Apa yang seharusnya siswa dapat lakukan?". Untuk itu diskusi mengenai penulisan CP juga dilakukan dengan peserta pelatihan dengan memberikan contoh-contoh CP. Selanjutnya diberikan juga contoh-contoh tugas (task) yang dapat menilai kemampuan belajar siswa secara otentik. Setelah itu mereka diminta merancang draf penilaian yang merujuk kepada CP sebuah KD. Kegiatan pada hari ini juga mensosialisasikan bagaimana 


\section{Suluah Bendang: Jurnal IImiah Pengabdian Kepada Masyarakat}

membuat rubrik skoring dan baik secara mandiri maupun bantuan dari website. Pelatihan diakhiri dengan pemberian tugas kepada peserta untuk membuat penilaian otentik yang akan didiskusikan pada pertemuan berikutnya.

Kemudian dilanjutkan pada pertemuan kedua pada tanggal 10 September 2019. Pada kesempatan ini Fitrawati, S.S., M.Pd melanjutkan materi tentang penilaian otentik. Pemateri memberikan materi dengan lebih spesifik yaitu mengelompokkannya pada oral skill: mendengar (listening) dan berbicara (speaking). Pemateri mengambil satu KD sebagai contoh dan kemudian merumuskan CP nya. Setelah itu peserta diminta untuk merancang penilaian otentik berdasarkan CP yang telah dirumuskan tadi. Pemateri juga memberikan teknik merancang penilaian otentik dan instrumen penilaiannya. Instrumen penilaian penting dibuat untuk setiap ujian atau tugas yang diberikan kepada siswa. Walau pada pertemuan sebelumnya telah dibahas juga tentang rubrik penilaian, dalam pertemuan kali ini dibahas dengan lebih mendalam lagi.

Pada kegiatan pelatihan hari ke-3 dan ke-4 masing-masing diberikan oleh Dra. Yetty Zainil, M.A., PhD dan Sitti Fatimah, S.S., M.Ed., PhD, fokus kegiatan adalah mendiskusikan tugas yang telah diberikan pada pelatihan di hari ke-1 dan ke-2. Pemateri juga memberikan umpan balik terhadap penilaian otentik yang telah dibuat oleh guru-guru (lihat Lampiran 3 sebagai contoh). Dari hasil kegiatan pada dua hari tersebut dapat dilihat bahwa sebagian guru-guru masih cenderung menggunakan penilaian tradisional. Walaupun tidak memungkinkan untuk memberikan penilaian otentik untuk semua tugas dan ujian, sebaiknya penilaian otentik lebih banyak diberikan.

Kemudian pada tahap refleksi guru diminta untuk menyampaikan keberhasilan berupa kemampuan merancang penilaian otentik. Sebagai bagian dari pelatihan pemateri juga meminta guru menyampaikan kelemahan yang ditemukan dari kegiatan pelatihan pembuatan penilaian otentik ini. Dan terakhir guru diharapkan untuk menindak lanjuti kegiatan ini sebagai upaya untuk menerapkan pembuatan penilaian otentik dalam pembelajaran bahasa Inggris di sekolah mereka masing- masing.

\section{KESIMPULAN}

Penilaian otentik adalah bentuk penilaian yang dibuat oleh guru yang merujuk pada kehidupan nyata siswa. Dengan jenis penilaian ini guru akan lebih mampu mendapatkan gambaran yang lebih jelas tentang kemampuan siswanya. Dalam pembelajaran bahasa Inggris penilaian otentik melibatkan kemampuan guru merumuskan capaian pembelajaran siswa.Dengan telah dilakukannya pelatihan pembuatan penilaian otentik terhadap guru-guru SMP di kota Padang, setidaknya ada dua hal penting yang dapat diketahui: 1) guru masih belum terlalu mampu merumuskan capaian pembelajaran dengan tepat; 2) capaian pembelajaran yang belum rinci dan belum merujuk kepada indikator kompetensi menyebabkan kurangnya pemahaman dan keterampilan dalam membuat soal-soal berbasis otentik.

Pelatihan ini hendaknya bersifat kontinyu karena kemampuan guru dalam merancang penilaian otentik adalah salah satu tolak ukur dari keberhasilan guru tersebut melaksanakan pembelajaran

\section{DAFTAR PUSTAKA}

Anderson, L.W. \& Krathwohl. (2001). A taxonomy for learning, teaching, and assessing ( $A$ Revision of Bloom's Taxonomy of Educational Objectives). Abridge Edition. New York: David McKay Company.

Anderson, L.W. \& Krathwohl (2010). Kerangka Landasan untuk Pembelajaran, Pengajaran dan Asesmen (Revisi Taksonomi Pendidikan Bloom). Yogyakarta: Pustaka Pelajar. 
Badan Standar Nasional Pendidikan (2007). Peraturan Menteri Pendidikan Nasional Republik Indonesia Nomor 41 Tahun 2007 Tentang Standar Proses untuk Satuan Pendidikan Dasar dan Menengah. Jakarta.

Badan Standar Nasional Pendidikan. (2004). Undang-undang Republik Indonesia Tentang Sistem Pendidikan Menengah. Jakarta: Depdiknas RI

Brown, H. D. (2010). Language Assessment: Principles and classroom practice (2nd Ed.). New York: Pearson Education, Inc.

Menteri Pendidikan \& Kebudayaan Republik Indonesia. (2018). Peraturan Menteri Pendidikan dan Kebudayaan Republik Indonesia Nomor 37 Tahun 2018 tentang Perubahan atas Peraturan Menteri Pendidikan dan Kebudayaan Nomor 24 Tahun 2016 Tentang Kompetensi Inti dan Kompetensi Dasar Pelajaran Pada Kurikulum 2013 Pada Pendidikan Dasar dan Pendidikan Menengah. Jakarta: Kemendikbud.

Moore, B \& Stanley, T. (2010). Critical Thinking and Formative Assessment. Larchmont: Eye of Education

Mulyasa, E. (2009). Standar kompetensi dan Sertifikasi Guru. Bandung: Remaja Rosdakarya 